\title{
Peran Keluarga dalam Meningkatkan Status Gizi pada Lansia
}

\author{
Cahya Tribagus Hidayat, Ali Usman \\ Fakultas Ilmu Kesehatan Universitas Muhammadiyah Jember, Jl. Karimata No. 49 \\ Kecamatan Sumbersari Kabupaten Jember, Jawa Timur \\ Email: cahyatribagus@unmuhjember.ac.id \\ Diterima tanggal \\ : 25 Maret 2020 \\ Direvisi tanggal \\ : 25 April 2020 \\ Dipublikasikan tanggal : 11 Juni 2020
}

\begin{abstract}
Abstrak
Latar Belakang dan Tujuan: Kebutuhan gizi yang tidak terpenuhi pada lansia akan meningkatkan risiko gizi buruk. Hal ini disebabkan oleh permasalahan sosial ekonomi dan meningkatnya penyakit degeneratif menjadikan keluarga pada posisi yang sangat penting dalam penyediaan gizi keluarga melalui fungsi fungsional dan pengendalian. Tujuan penelitian ini adalah untuk mengetahui hubungan peran keluarga dengan status gizi lansia. Peran keluarga dalam memberikan gizi seimbang pada lansia diperlukan untuk mengoptimalkan status kesehatan lansia dan kualitas hidupnya.

Metode: Penelitian ini merupakan penelitian korelasional yang dilakukan dengan pendekatan cross sectional. Populasi dalam penelitian ini adalah lansia yang bertempat tinggal di Desa Kaliwates Jember dan responden yang mengambil bagian dalam penelitian ini diambil secara purposive sampling. Analisis chi square digunakan untuk mengetahui hubungan antara dua variabel.

Hasil: Sebagian besar peran keluarga dalam kategori baik sebanyak 23 responden $(44,3 \%)$. Status gizi berdasarkan BB/U mayoritas baik sebanyak 30 responden $(57,7 \%)$, status gizi berdasarkan $\mathrm{TB} / \mathrm{U}$ mayoritas baik sebanyak 28 responden $(53,8 \%)$. Berdasarkan hasil uji statistik Chi Square menunjukkan nilai p 0,001 < 0,05 sehingga dapat dikatakan terdapat yang signifikan antara peran keluarga dengan status gizi lansia.
\end{abstract}

Simpulan dan Implikasi: Peran keluarga mempengaruhi status gizi lansia karena keluarga merupakan sistem pendukung terbesar dalam kehidupan lansia dan pengasuhan lansia merupakan tanggung jawab keluarga. Dengan demikian maka intervensi keperawatan untuk meningkatkan optimalisasi peran keluarga dibutuhkan agar status gizi lansia juga dapat ditingkatkan.

Kata kunci: Lansia; Peran keluarga; Status gizi

Sitasi: Hidayat CT \& Usman A. (2020). Peran keluarga dalam meningkatkan status gizi pada lansia. The Indonesian Journal of Health Science. 12(1), 34-39

Copyright: () 2020 Hidayat et al. This is an open-access article distributed under the terms of the Creative Commons Attribution License, which permits unrestricted use, distribution, and reproduction in any medium, provided the original author and source are credited.

Diterbitkan Oleh: Universitas Muhammadiyah Jember

ISSN (Print): 2087-5053

ISSN (Online): 2476-9614 


\begin{abstract}
Abstrack
Introduction: Unfulfilled nutritional need of elerly will lead to the increase of malnutrition risk. It caused by the social economic problems and the increase of degenerative disease making the family at crucial position in providing nutrition of family through functional and controlling function. this study purpose was to determine the correlationship between family role and elderly nutritional status. Family role in providing balance nutrition in elderly is needed to optimize elderly health status and their quality of life.

Methods: This is a correlational study conducted with cross sectional approach. The population was eldelry living in Kaliwates village Jember and the respondents taking parts in this study was taken by purposive sampling. Chi square anaysis was used to determine the correlationship between two variables.

Result: Most of the family roles in the good category were 23 respondents (44.3\%). The majority of nutritional status based on weight/age were good as many as 30 respondents (57.7\%), the nutritional status based on height/age was mostly good as many as 28 respondents (53.8\%). Based on the results of the Chi Square statistical test, it shows a p value of $0.001<0.05$, so it can be said that there is a significant difference between the role of the family and the nutritional status of the elderly.

Conclusion: The role of family affects the nutritional status of the elderly because the family is the biggest support system in the life of the elderly and the care of the elderly is the responsibility of the family. Thus, nursing intervention to improve the optimization of the role of the family is needed so that the nutritional status of the elderly can also be improved.
\end{abstract}

Keywords: Elderly; Family role; Nutritional status

PENDAHULUAN

Penuaan adalah suatu proses alami yang tidak dapat dihindari, berjalan terus menerus, dan berkesinambungan. Selanjutnya akan menyebabkan perubahan anatomis, fisiologis dan bio kimia pada tubuh sehingga akan mempengaruhi fungsi dan kemampuan tubuh secara keseluruhan (Maryam, dkk, 2009).

Untuk mengkompensasi terjadinya penurunan fungsi fisiologis lansia dan berbagai masalah yang menyertai pada pereiode ini, maka harus diberikan nutrisi yang cukup pada lansia agar sesuai dengan aktivitas lansia. Asupan gizi seimbang sangat diperlukan bagi usia lanjut sehat maupun yang sakit untuk mempertahankan kualitas hidupnya serta diperlukan dalam proses penyembuhan dan mencegah agar tidak terjadi komplikasi lebih lanjut dari penyakit yang dideritanya (Maryam, dkk, 2009). enjaga nutrisi yang baik harus di tekankan pada lanjut usia, karena lanjut usia dengan nutrisi yang terpenuhi tidak hanya merasa lebih nyaman dan kuat tetapi juga akan lebih cepat sembuh dan mengalami lebih sedikit komplikasi penyakit. Kondisi kesehatan pada tahap ini sangat di tentukan oleh kualitas dan kuantitas makanan yang bergizi serta seimbang. Nutrisi yang baik akan berperan dalam upaya presentasi timbulnya penyakit. Salah satu 
faktor penunjang dalam pengawasan dan alat kontrol pemberian asupan gizi pada lansia adalah keluarga.

Peran keluarga dalam
pemenuhan
yang seimbang pada lansia sangat diperlukan agar tercapainya status kesehatan lansia yang optimal sehingga kualitas hidup lansia dapat meningkat. Tetapi, kenyataan yang ada di masyarakat masih terdapat keluarga yang menganggap sederhanya masa lah pemenuhan gizi lansia, karena keluarga beranggapan bahwa pada lansia dalam sudah mulai mengalami penurunan fungsi pencernaan yang disebabkan oleh proses penuaan.

Data yang didapatkan pada tahun 2019, jumlah lansia Indonesia diproyeksikan akan meningkat menjadi 27,5 juta atau $10,3 \%$, dan 57,0 juta jiwa atau $17,9 \%$ pada tahun 2045 (BPS, Bappenas, U NFPA, 2018). sedangkan data yang diperoleh dari penelitian Setiani (2012) bahwa lansia yang mengalami kurang gizi sebanyak $3,4 \%$, berat badan kurang sebesar $28,3 \%$, berat badan ideal berjumlah $42,4 \%$, berat badan lebih sebanyak $6,7 \%$ dan obesitas sebanyak $3,4 \%$, sedangkan konsumsi energi dan protein rata - rata lansia. Berdasarkan hasil survei pendahuluan yang dilakukan diwilayah kerja Puskesmas kaliwates Kabupaten Jember, didapatkan data bahwa dari 105 jumlah lansia di Kelurahan Kaliwates Kecamatan Kaliwates sejumlah 52 jiwa mengalami gangguan pemenuhan kebutuhan nutrisi. Hal tersebut menunjukkkan bahwa masalah pemenuhan kebutuhan gizi pada lansia masih tinggi.

Kebutuhan nutrisi yang tidak terpenuhi pada lanjut usia akan mengakibatkan terjadinya nutrisi yang kurang, hal tersebut disebabkan oleh masalah-masalah sosial ekonomi dan juga gangguan penyakit, bila konsumsi kalori yang terlalu rendah dari yang dibutuhkan menyebabkan berat badan kurang dari normal. Apabila hal ini disertai dengan kerusakan-kerusakan sel yang tidak dapat diperbaiki, akibatnya rambut rontok dan daya tahan tubuh menurun (Nugroho, 2012)

\section{METODE PENELITIAN}

Jenis penelitian adalah penelitian kuantitatif, dimana rancangan penelitian yang dipakai menggunakan pendekatan cross sectional. Proses pengumpulan data dilakukan dengan menggunakan kuesioner.

Populasi dalam penelitian ini adalah lansia yang ada di Kelurahan Kaliwates Kecamatan Kaliwates Kabupaten Jember dengan jumlah 105 orang. Sampel penelitian adalah 52 responden dengan teknik pengambilan sampel menggunakan purposive sampling. Instrumen penelitian ini berupa kuesioner tentang peran keluarga. Sedangkan untuk pengukuran status gizi menggunakan lembar observasi berdasarkan parameter berat badan dan tinggi badan sesuai kategori $\mathrm{Z}$ Score. Hasil pengukuran status gizi dikelompokkan menjadi tiga. (Tabel 1). Analisis data menggunakan uji statistik korelasi non parametrik yaitu uji korelasi dengan batas kemaknaan $(\alpha=0,05)$. 
HASIL

Hasil penelitian diketahui bahwa sebagian besar peran keluarga dalam kategori baik sebanyak 23 responden $(44,3 \%)$ (Tabel 2). Status gizi baik berdasarkan $\mathrm{BB} / \mathrm{U}$ sebanyak $30(57,7 \%)$, status gizi tidak baik berdasarkan BB/U sebanyak 22 (42,3\%), status gizi baik berdasarkan TB/U sebanyak 28
$(53,8 \%)$ sedangkan status gizi tidak baik berdasarkan TB/U sebanyak 24 $(46,2 \%)$ (Tabel 3). Berdasarkan hasil uji statistik Chi Square menunjukkan nilai $\mathrm{p} 0,001<0,05$ sehingga dapat dikatakan bahwa uji statistik tersebut bermakna atau dengan kata lain terdapat hubungan peran keluarga dengan status gizi pada lansia (Tabel 4; Tabel 5).

Tabel 1. Parameter Status Gizi

\begin{tabular}{cc}
\hline Status Gizi & IMT \\
\hline Kurus & $<18,5$ \\
Normal & $18,5-25$ \\
Gemuk & $25,1-27$ \\
Obesitas & $>27$ \\
\hline
\end{tabular}

Tabel 2. Kategori Peran Keluarga pada Lansia

\begin{tabular}{lll}
\hline Kategori Peran Keluarga & Frekuensi & Persentase \\
\hline Baik & 23 & 44,3 \\
Cukup & 28 & 34,6 \\
Kurang & 11 & 21,1 \\
\hline
\end{tabular}

Tabel 3. Distribusi Status Gizi Lansia

\begin{tabular}{|c|c|c|c|c|c|}
\hline \multirow{3}{*}{$\begin{array}{c}\text { Indikator status } \\
\text { Gizi }\end{array}$} & \multicolumn{4}{|c|}{ Status Gizi } & \multirow{3}{*}{$\frac{\text { Total }}{\mathrm{N}}$} \\
\hline & \multicolumn{2}{|c|}{ Baik } & \multicolumn{2}{|c|}{ Tidak baik } & \\
\hline & $\mathrm{N}$ & $\%$ & $\mathrm{~N}$ & $\%$ & \\
\hline $\mathrm{BB} / \mathrm{U}$ & 30 & 57,7 & 22 & 42,3 & 52 \\
\hline $\mathrm{TB} / \mathrm{U}$ & 28 & 53,8 & 24 & 46,2 & 52 \\
\hline
\end{tabular}

Tabel 4. Analisis Peran Keluarga dengan Status Gizi pada Lansia (BB/U)

\begin{tabular}{|c|c|c|c|c|c|}
\hline \multirow{3}{*}{ Peran Keluarga } & \multicolumn{4}{|c|}{ Status Gizi BB/U } & \multirow{3}{*}{$\begin{array}{c}\mathrm{P} \\
\text { Value }\end{array}$} \\
\hline & \multicolumn{2}{|c|}{ Baik } & \multicolumn{2}{|c|}{ Tidak baik } & \\
\hline & $\mathrm{N}$ & $\%$ & $\mathrm{~N}$ & $\%$ & \\
\hline Baik & 17 & 32,6 & 6 & 11,6 & 0,001 \\
\hline Cukup & 12 & 23 & 6 & 11,6 & \\
\hline Kurang & 7 & 13,5 & 4 & 7,7 & \\
\hline
\end{tabular}

Tabel 5. Analisis Peran Keluarga dengan Status Gizi pada Lansia (TB/U)

\begin{tabular}{|c|c|c|c|c|c|}
\hline \multirow{3}{*}{ Peran Keluarga } & \multicolumn{4}{|c|}{ Status Gizi TB/U } & \multirow{3}{*}{$\begin{array}{c}\mathrm{P} \\
\text { Value }\end{array}$} \\
\hline & \multicolumn{2}{|c|}{ Baik } & \multicolumn{2}{|c|}{ Tidak baik } & \\
\hline & $\mathrm{N}$ & $\%$ & $\mathrm{~N}$ & $\%$ & \\
\hline Baik & 22 & 42,3 & 3 & 5,8 & 0,001 \\
\hline Cukup & 16 & 30,8 & 5 & 9,6 & \\
\hline Kurang & 4 & 7,7 & 2 & 3,8 & \\
\hline
\end{tabular}




\section{PEMBAHASAN}

Hasil

menunjukkan mayoritas lansia memiliki status gizi yang normal. Hail penelitian ini sejalan dengan penelitian dari Alao eta al yang menyatakan BMI normal pada lansia mengindikasikan konsumsi makanan lansia telah memenuhi kebutuhan tubuh. Secara umum lansia adalah kelompok populasi rentan. Lansia rentan mengalami malnutrisi akibat berbagai macam faktor. Perubahan fisiologis yang menyebabkan lansia beresiko mengalami perubahan nafsu makan serta adanya comorbid yang menimbulkan perubahan metabolisme berkontribusi terhadap status nutrisi lansia. DI sisi lain, secara ekonomi, dimana lansia bukan lagi kelompok produktif dan umumnya tidak lagi memiliki penghasilan yang tetap akan mempengaruhi kemampuan lansia dalam membeli makanan sesuai dengan kebutuhannya. Untuk itulah peran keluarga sangat dibutuhkan oleh lansia.

Penelitian yang dilakukan
oleh Pradnyani et al (2016)
menyebutkan lansia, Keluarga merupakan pemberi dukungan utama dalam kehidupan lansia, utamanya lansia di negara berkembang. Merawat anggota kleuarga yang memasuki usia lansia adalah suatu kwajiban bagi keluarga. Adapun bentuk dukungan yang diberikan keluarga dapat berupa dukungan ekonomi (penyediaan dana), penyediaan makanan hingga penjaminan biaya kesehatan. Peran keluarga bagi lansia di Indonesia sangat vital. Keluarga merupakan support system terpenting bagi lansia. Mayoritas lansia di Indonesia tinggal bersama anak dan anggota keluarga lainnya.

Norma ketimuran dan nilai agama yang dianut oleh keluarga dapat dikatakan berpengaruh pada bentuk dukungan keluarga pada lansia. Nilai keluarga yang berkenaan dengan lansia yang masih banyak dianut oleh keluarga di Indonesia menyebutkan bahwa seorang anak harus berbakti pada orang tua. Hal ini juga diperkuat oleh ajaran Islam yang banyak dianut oleh penduduk Indonesia. Ajaran Islam mengatakan bahwa anak laki - laki bertanggung jawab untuk menjaga ibunya meski dalam kondisi telah menikah. Kepatuhan terhadap ajaran agama sedikit banyak juga mengarahkan bentuk dukungan keluarga terhadap lansia. Bentuk kepatuhan terhadap ajaran agama diwujudkan keluarga dengan merawat lansia dengan baik sebagai bentuk pengabdian seorang anak. Perawatan keluarga yang baik diwujudkan dalam bentuk pemenuhan kebutuhan gizi lansia dan pemenuhan kebutuhan ekonomi lansia lainnya yang berkontribusi terhdap peningkatan kualitas hidup lansia.

\section{SIMPULAN}

Berdasarkan analisis data dan pembahasan dalam penelitian ini maka penulis dapat menyimpulkan bahwa terdapat hubungan antara peran keluarga dengan status gizi pada lansia di kelurahan Kaliwates Kecamatan kaliwates kabupaten Jember.

\section{SARAN}

Bagi petugas kesehatan dihara pkan secara rutin dapat memberikan penyuluhan kepada orang tua tentang pentingnya pengetahuan tentang gizi 
balita.Bagi keluarga untuk selalu me mperhatikan status gizi lansia dengan selalu memperhatikan menu dan gizi makanan yang dikonsumsi setiap hari dan secara rutin memotivasi lansia ikut serta ke posyandu lansia setiap bulannya untuk dilakukan penimbangan. Bagi peneliti selanjutnya diharapkan dapat dijadikan bahan referensi dari hasil penelitian yang sudah ada dan dapat menjadi acuan untuk mengembangkan penelitian kearah yang lebih luas.

\section{DAFTAR PUSTAKA}

Alimul Hidayat, A Aziz. 2007. Metode

Penelitin Keperawatan dan

Teknik Analisis.

Data.

Jakarta: Salemba Medika

Andarmoyo, Sulistyo. 2012.

Keperawatan Keluarga

Konsep Teori, Proses dan

Praktik Keperawatan.

Yogyakarta : Graha Ilmu

Ariani, 2017,Ilmu GIzi, Yogyakarta, Nuha Medika

Azizah, Lilik Ma'rifatul (2011).

Keperawatan Lanjut Usia.

Yogyakarta : Graha Ilmu

Bappenas, BPS, UNFPA. 2018.

Proyeksi Penduduk

Indonesia 2005-2025. Jakarta:

Badan Pusat Statistik

Dewi, Sofia Rhosma. (2014). Buku Ajar Keperawatan Gerontik. Yogyakarta: Penerbit Deepublish

Mardalena, Ida. (2017). Dasar-Dasar Ilmu Gizi Dalam

Keperawatan Konsep dan Penerapan Pada Asuhan Keperawatan. Yogyakarta : Pustaka Baru Press

Maryam, R. Siti, dkk. (2008). Mengenal Usia lanjut dan
Perawatannya. Jakarta : Salemba Medika

Nugroho .(2012). "Faktor-Faktor yang Mempengaruhi Intellectul capital Disclousure". Accounting Analysis journal . 1 (2)

Sugiyono. 2017. Metode Penelitian Kuantitatif, Kualitatif, dan R\&D. Bandung: Afabeta 